\title{
Indicators of the energy supply system in the liver of rats under the conditions of different nutrients content in a diet
}

\author{
O. M. Voloshchuk, G. P. Kopylchuk \\ Yuriy Fedkovych Chernivtsi National University \\ 2, Kotsjubynskyi Str., Chernivtsi, Ukraine, 58012 \\ o.voloschuk@chnu.edu.ua
}

\begin{abstract}
Aim. The features of the energy supply in hepatocytes of rats under the conditions of different content of protein and sucrose in a diet were studied in the research. Methods. Experimental diets, differential centrifugation, spectrophotometry, chromatography on sheets. Results. It was found that 4-week maintenance of animals on a low-protein diet resulted in a 2.2-fold decrease in the succinate dehydrogenase activity, a threefold reduction of the cytochrome oxidase activity, and an increase in the F0F1-ATPase activity in a 1.5-fold in hepatocytes of rats. Under the experimental conditions, a $40 \%$ decrease in the ATP content was found in the rat hepatocytes mitochondria against the background of an increase in the ADP content and maintaining the AMP content at the control level. It should be noted that under the conditions of the high-sucrose diet no significant changes in the succinate dehydrogenase activity were found in hepatocytes mitochondria; however, the cytochrome oxidase activity decreased by half and the F0F1-ATPase activity increased by 1.8 times. The most significant changes in the energy supply of hepatocytes occurred in the conditions of low-protein/high-sucrose diet. A sixfold decrease in the succinate dehydrogenase activity and reduction of the cytochrome oxidase activity to critically low values was found. With that, a twofold increase in the F0F1ATPase activity compared to control was accompanied by a depletion of the pool of adenyl nucleotides. Conclusions. It is concluded that the lack of protein in the diet is a determining factor for the system of energy supply and the functioning of the respiratory chain, while the imbalance in the diet in terms of the content of food protein and sucrose is critical for the formation of an imbalance in energy supply to hepatocytes. The obtained results open up the prospects for developing a strategy of correcting energy metabolism disorders in conditions of nutritional imbalance.
\end{abstract}

Ke y w or d s: succinate dehydrogenase, cytochrome oxidase, $\mathrm{F}_{0} \mathrm{~F}_{1}$-ATPase, liver, nutrients

(C) 2021 O. M. Voloshchuk et al.; Published by the Institute of Molecular Biology and Genetics, NAS of Ukraine on behalf of Biopolymers and Cell. This is an Open Access article distributed under the terms of the Creative Commons Attribution License (http://creativecommons.org/licenses/by/4.0/), which permits unrestricted reuse, distribution, and reproduction in any medium, provided the original work is properly cited 


\section{Introduction}

Nowadays, the modern diets are characterized by an imbalance in the nutrient composition: the products low in protein and rich in sucrose are widespread, which leads to a high prevalence of overweight and obesity [1]. Chronic consumption of large amounts of sucrose with simultaneous lack of protein in the diet may act as a factor of induction and progression of metabolic disorders. The mentioned diets may be considered extreme and cause significant changes in the normal balance between the products of cell metabolism. In the organs with intense energy processes, e.g. in the liver, the altered metabolic conditions could affect the cellular regulatory mechanisms [2].

Under these conditions, the cells must adapt fuel oxidation processes (amino acid oxidation, glycolysis and beta-oxidation) to ensure the availability of energy substrates. This metabolic flexibility is critical for adapting the organism to different physiological conditions, allowing the switch from one fuel to another in response to the dietary changes [3]. The discovery of the relationship between the peculiarities of the nutritional composition of the diet and the intensity of metabolic transformations in mitochondria can become the basis for understanding the pathophysiological mechanisms of mitochondrial diseases [3].

Studying the high-sucrose diet we have found a mild effect on body weight gain and fasting blood glucose levels, but a significant increase in triglycerides, insulin resistance and visceral fat accumulation [4]. Mitochondrial function was impaired due to multiple defects affecting the respiratory chain complex I and IV, pyruvate uptake and several b-oxidation enzymes, which led to strongly reduced hepatic ATP levels in the low protein diet-fed rats [5]. To date, the features of bioenergetic processes and functioning of mitochondria in conditions of the high-sucrose and low-protein diet consumption in young adult rats have not been studied. The state of energy supply to cells is primarily determined by the efficiency of the functioning of the respiratory chain of mitochondria, which converts the energy of substrate oxidation into a transmembrane difference in the electrochemical potentials of hydrogen ions on the membrane [6]. The important indicators of the energy metabolism are the activities of succinate dehydrogenase (1.3.5.1), cytochrome c oxidase (1.9.3.1), $\mathrm{F}_{1} \mathrm{~F}_{\mathrm{o}}$ ATP synthase (3.6.3.14), and adenyl nucleotides content [7].

The research aimed to study the state of the liver cellular energy supply system under the conditions of sucrose-enriched and low-protein diet consumption.

\section{Materials and Methods}

In the study, 9-10 week old white nonlinear rats weighing $110-120 \mathrm{~g}$ were used. The animals were separated into solitary plastic cages and ad libitum access to water. They were housed at a controlled temperature of $20{ }^{\circ} \mathrm{C} \pm 2{ }^{\circ} \mathrm{C}$ with a 12 -hour light-dark cycle. The animals were monitored daily, weighed three times/week. All manipulations were conducted according to the general ethical principles of experiments on animals adopted by the Sixth National Congress of Ukraine on Bioethics [8], in accordance with international bioethical norms [9] and approved by bio- 
ethics commission of the Institute of the biology, chemistry and biological resources of Yuriy Fedkovych Chernivtsi National University.

The animals were divided into the following experimental groups: I - animals receiving full-value semi-synthetic ration (C); II - animals receiving low-protein ration (LP); III animals receiving high-sucrose diet (HS); IV - animals receiving low-protein high-sucrose diet (LP/HS).

The control diet $(\mathrm{C})$ was the AIN-93 diet [10], all ingredients are presented in Table 1.

The animals of the group II received isoenergetic ration containing $4.7 \%$ of protein. The animals of the group III received high-sucrose diet containing $40 \%$ of sucrose and balanced by all other essential nutrients [11]. The animals of the group IV received isoenergetic ration containing $4.7 \%$ of protein, $40 \%$ of sucrose and balanced by all other essential nutrients. The animals were maintained on the corresponding diet during four weeks. Cervical

Table 1. Ingredient composition of the diets (g/kg diet)

\begin{tabular}{l|c|c|c|c}
\hline \multirow{2}{*}{ Ingredient } & \multicolumn{4}{c}{ Diet } \\
\cline { 2 - 5 } & $\mathrm{C}$ & LP & HS & LP/HS \\
\hline Cornstarch, g/kg & 620.7 & 714.1 & 320.7 & 414,1 \\
\hline Casein, g/kg & 140 & 46,6 & 140 & 46,6 \\
\hline Sugar, g/kg & 100 & 100 & 400 & 400 \\
\hline $\begin{array}{l}\text { Fiber (cellulose } \\
\text { microfiber), g/kg }\end{array}$ & 50 & 50 & 50 & 50 \\
\hline Mineral mix, g/kg1 & 35 & 35 & 35 & 35 \\
\hline Vitamin Mix, g/kg1 & 10 & 10 & 10 & 10 \\
\hline L-Cystine, g/kg $/ \mathrm{kg}^{1}$ & 1.8 & 1.8 & 1.8 & 1.8 \\
\hline Choline bitartrate, g/kg & 2.5 & 2.5 & 2.5 & 2.5 \\
\hline Soy Oil, g/kg & 40 & 40 & 40 & 40 \\
\hline
\end{tabular}

1 Mineral and Vitamin Mix - Based on the AIN-93G vitamin and mineral mixes dislocation was performed under the light ether anesthesia on day 29 of the experiment.

Hepatic tissue samples were weighed and homogenized in homogenizing buffer $(1: 4)$ (250 mM sucrose, $1 \mathrm{mM}$ EDTA, $10 \mathrm{mM}$ Tris$\mathrm{HCl} ; \mathrm{pH}$ 7.4). Mitochondrial fraction of the liver homogenate was separated by differential centrifugation (Heraeus Biofuge, Germany) at $0-3{ }^{\circ} \mathrm{C}[12]$. The protein content of the tissue homogenates was measured using the Bradford method [13].

The succinate dehydrogenase activity was measured based on restoration of potassium ferricyanide $\left(\mathrm{K}_{3}\left[\mathrm{Fe}(\mathrm{CN})_{6}\right]\right)$ to potassium ferrocyanide $\left(\mathrm{K}_{4}\left[\mathrm{Fe}(\mathrm{CN})_{6}\right]\right)$ by the action of succinate dehydrogenase [14]. The mitochondria $(0.1 \mathrm{mg}$ of protein) were suspended in $50 \mathrm{mM}$ (K) phosphate buffer ( $\mathrm{pH}$ 7.4) containing 3 $\mathrm{mM}$ potassium ferricyanide (III) acting as an exogenous electron acceptor. A decrease in the absorption $(420 \mathrm{~nm})$ upon the addition of 50 $\mathrm{mM}$ succinate was followed to measure the rate of potassium ferrocyanide (II) formation at $30{ }^{\circ} \mathrm{C}$ for $2 \mathrm{~min}$. The reaction rate was calculated as nmol ferrocyanide formed per minute per mg protein $\left(\varepsilon_{420}\right.$ for potassium ferricyanide $\left.=1040 \mathrm{M}^{-1} \mathrm{~cm}^{-1}\right)$. Pure mitochondria pretreated with $500 \mathrm{mM}$ malonate, a competitive inhibitor of $\mathrm{SDH}$, were used as a negative control.

Cytochrome oxidase activity was determined by the method based on the ability of cytochrome oxidase to oxidize dimethylparaphenylenediamine and $\alpha$-naphthol (NADI reagent) to form a colored product [15]. Its concentration is proportional to [the] cytochrome oxidase activity. The samples were measured spectrophotometrically at $\lambda 550 \mathrm{~nm}$. 
$F_{0} F_{1}$-ATPase activity was evaluated according to the accumulation of $\mathrm{P} i[16]$. The activity was determined in the incubation solution containing $400 \mu \mathrm{mol}$ of tris- $\mathrm{HCl}(\mathrm{pH} 7.4)$, $5 \mu \mathrm{mol}$ of ATP disodium salt, $7.5 \mu \mathrm{mol}$ of $\mathrm{MgSO}_{4}, 1 \cdot 10^{-2} \mu \mathrm{mol}$ of 2,4-dinitrophenol, $7.5 \mu \mathrm{mol}$ of $\mathrm{CaCl}_{2}, 120 \mu \mathrm{mol}$ of $\mathrm{NaCl}, 20 \mu \mathrm{mol}$ of $\mathrm{KCl}$. The reaction was initiated by the addition of $50 \mu \mathrm{l}$ of a mitochondria suspension containing $1 \mathrm{mg}$ of protein, incubated for 15 min at $37^{\circ} \mathrm{C}$. The contents of $\mathrm{P} i$ were determined colorimetrically.

Quantitative evaluation of the ATP, ADP, and AMP content was performed by thin-layer chromatography on Silufol sheets [17]. Free nucleotides were extracted from the mitochondrial fraction with $0.8 \mathrm{M} \mathrm{HClO}_{4}$ for $30 \mathrm{~min}$ at $0-4{ }^{\circ} \mathrm{C}$. Protein-free perchlorate extracts were obtained by centrifugation for $15 \mathrm{~min}$ at 1500 g. Supernatants were neutralized with $\mathrm{K}_{2} \mathrm{CO}_{3}$ to $\mathrm{pH} 7.0$ and centrifuged again under the same conditions, upon which the supernatant aliquots were loaded onto chromatographic sheets. After adenyl nucleotides were separated in the mobile phase composed of diox- ane, isopropanol, water, and ammonia (4:2:4:1), they were quantitatively determined by direct spectrometry. Nucleotide spots were detected in UV light and eluted from the sheets with $0.1 \mathrm{M} \mathrm{HCl}$ for $20 \mathrm{~min}$. The eluate absorption was measured at $260 \mathrm{~nm}$.

Data analysis and statistics. The data were compared and analyzed by using unpaired T-test. Characteristics of the study group were expressed as Mean \pm Standart Deviation for normal distribution. For all statistical calculations, significance was considered to be a value of $\mathrm{P} \leq 0.05$.

\section{Results and Discussion}

The study of indicators of the state of the energy biotransformation system in the liver of rats kept on the low-protein diet showed a 2.2-fold decrease in the activity of succinate dehydrogenase (Fig. 1). Simultaneously, the activity of cytochrome oxidase (Fig. 2) decreased threefold. Additionally, a decrease in the activity of the studied respiratory chain enzymes was accompanied by a significant increase in the F0F1-ATPase activity in mito-

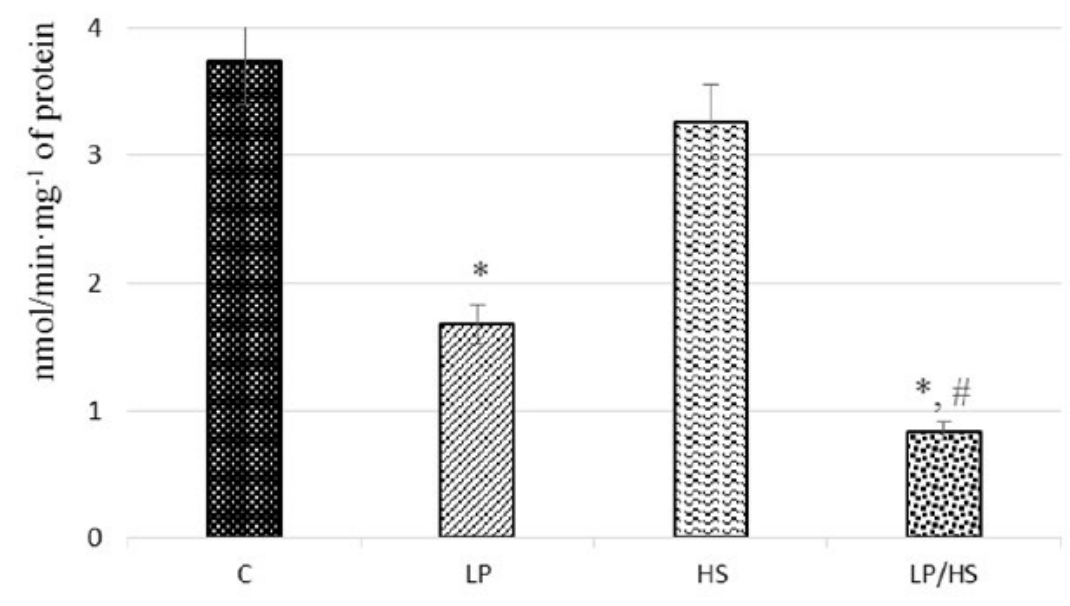

Fig. 1. Activity of succinate dehydrogenase in the rat liver mitochondrial fraction under the conditions of different nutrients content in a diet

(Note (here and forwards): C - animals receiving complete semi-synthetic ration; $L P$ - animals receiving lowprotein ration; $H S$ - animals receiving high-sucrose diet; LP/HS - animals receiving low-protein high-sucrose.

* significantly different from the control, $P \leq 0.05$;

\# significantly different from the group $H S, P \leq 0.05$.) 

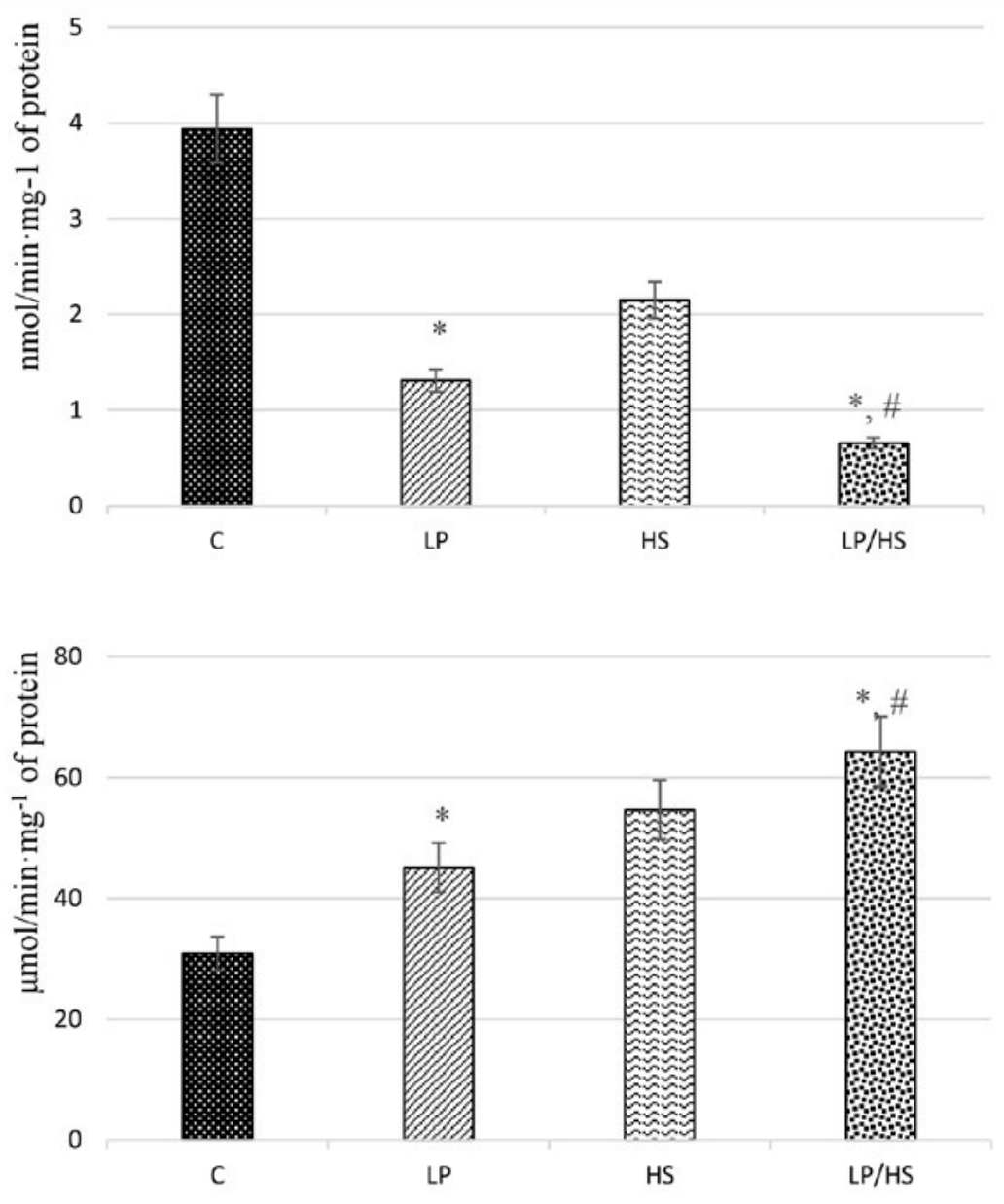

Fig. 2. Activity of cytochrome oxidase in the rat liver mitochondrial fraction under the conditions of different nutrients content in a diet
Fig. 3. Activity of $\mathrm{F}_{0} \mathrm{~F}_{1}$-ATPase in the rat liver mitochondrial fraction under the conditions of different nutrients content in a diet chondria (Fig. 3). Under the experimental conditions, a $40 \%$ decrease in the ATP content was found in the rat liver mitochondria (Fig. 4) against the background of an increase in the ADP content (Fig. 5) and maintaining the AMP content at the control level (Fig. 6).

A decrease in the activity of succinate dehydrogenase - the key enzyme of the II complex of the respiratory chain, acting as an intermediary between FAD-dependent substrates and electron transport chains [18], and cytochrome oxidase - the key enzyme of the terminal region of the respiratory chain, catalyzing the oxygen reduction reaction, indicates a decline in the efficiency of the oxidative phosphorylation under the conditions of a lowprotein diet. The reduction of $\mathrm{O}_{2}$ is a highly exergonic process, and it accompanies vectorial transport of protons across the inner mitochondrial membrane to contribute to the generation of proton motive force required for ATP synthesis. $\mathrm{CcO}$ acts as a control point (ratelimiting enzyme) in OxPhos [19]. It can be assumed that under the current experimental 

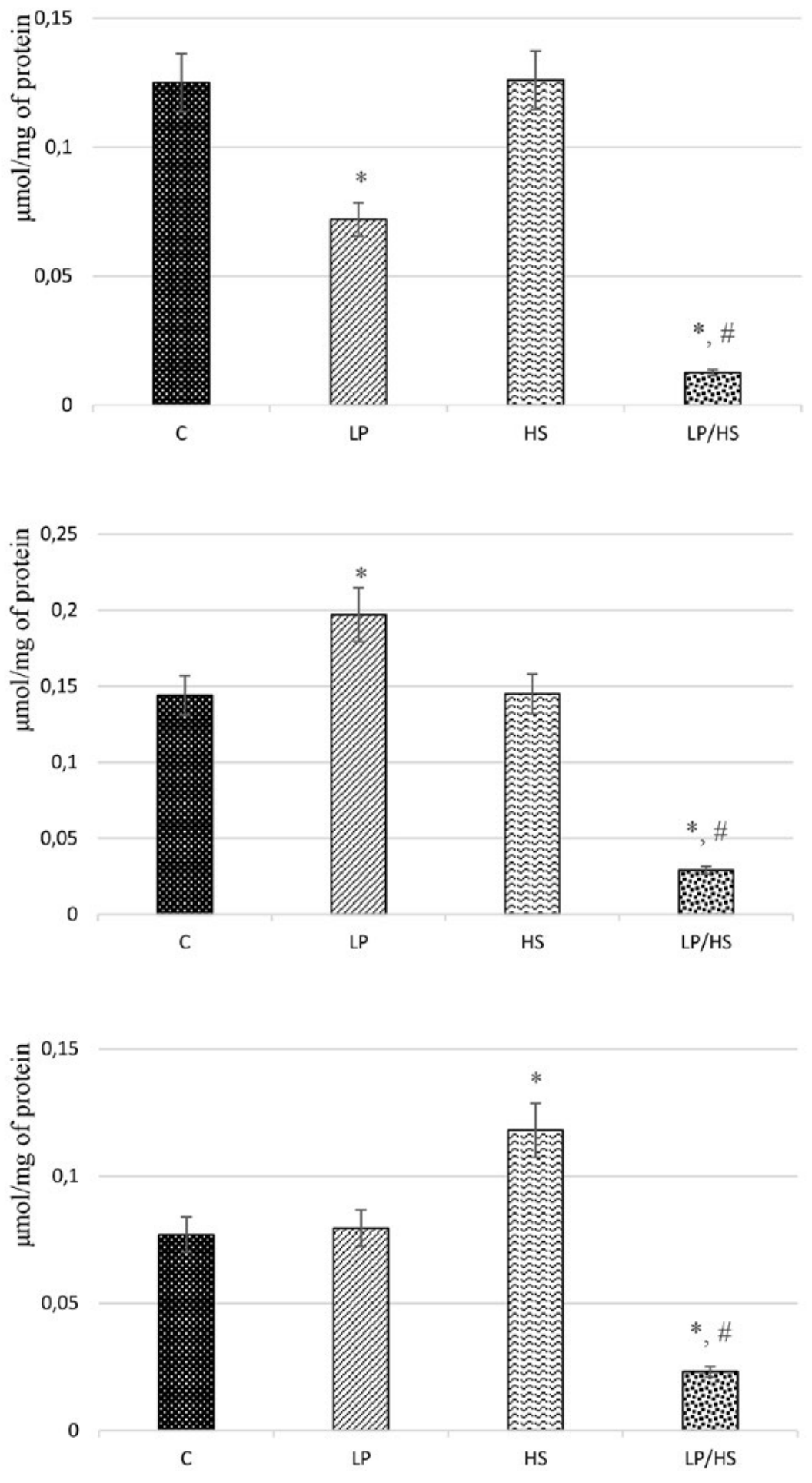

Fig. 4. The ATP content in the rat liver mitochondrial fraction under the conditions of different nutrients content in a diet

Fig. 5. The ADP content in the rat liver mitochondrial fraction under the conditions of different nutrients content in a diet

Fig. 6. The AMP content in the rat liver mitochondrial fraction under the conditions of different nutrients content in a diet 
conditions, a drop of the membrane potential and uncoupling of oxidative phosphorylation will be observed. The established changes can be associated with disturbances of the synthesis of the studied enzymes subunits under the conditions of a lack of protein in the diet. Additionally, an established significant increase in the F0F1-ATPase activity in mitochondria also indicates the uncoupling of oxidative phosphorylation under the chosen experimental conditions. F0F1-ATPase/ATPsynthase is localized in the inner mitochondrial membrane and plays a key role in maintaining energy supply to cells. This enzyme can also work in the reverse direction, hydrolyzing ATP and pumping protons under certain conditions, which is necessary to maintain the electrochemical potential [20]. At the same time, it is known that an increase in F0F1-ATPase activity is the reason for a decrease in the ATP concentration under certain pathological conditions [21]. Indeed, the established changes in the ATP and ADP content will likely lead to the disturbances of biosynthetic processes and intensification of catabolic processes in hepatocytes. Besides, the established depletion of the ATP pool in liver cells may result in the induction of hepatocytes death. It is known that cellular ATP is an important factor of cell death by apoptosis or necrosis [22].

On the other hand, the results of the studies showed no significant changes in the succinate dehydrogenase activity in the liver mitochondria of rats maintained on a high-sucrose diet (Fig. 1). Instead, under the conditions of excessive sucrose intake, a twofold decrease in the cytochrome oxidase activity in the liver mitochondria was found (Fig. 2). The absence of changes in the activity of succinate dehydrogenase and a simultaneous decrease in the cytochrome oxidase activity in the liver mitochondria under the conditions of excessive sucrose intake indicate that maintenance on the high-sucrose diet causes changes in the inner mitochondrial membrane permeability, which can be considered as an adaptive defence mechanism under the conditions of oxidative stress. It is known that a mild uncoupling of oxidative phosphorylation reduces the superoxide generation by decreasing the potential of the mitochondrial membrane [23]. Since excessive dietary consumption of sucrose induces the synthesis of free fatty acids (FFA) in the liver, which, according to the theory of lipotoxicity, can promote the formation of FFA metabolites that can trigger inflammation and generation of reactive oxygen species (ROS) [24], the uncoupling of oxidative phosphorylation under these conditions can have a great adaptive significance.

The obtained results showed a 1.8-fold increase in the F0F1-ATPase activity in the liver mitochondrial fraction of rats kept on the high-sucrose diet compared to the control (Fig. 3). Probably, an increase in [the] F0F1ATPase activity under the current conditions is due to a decrease in the membrane potential on the inner mitochondrial membrane, which may be the reason for the activation of oxidative processes in liver cells of rats maintained on the high-sucrose diet [25]. We have also found that under the studied conditions the amount of ATP (Fig. 4) and ADP (Fig. 5) in the mitochondrial fraction of the rat liver remained at the control level. At the same time, the AMP content in the mitochondrial fraction of rat liver almost doubles (Fig. 6). Probably, 
the revealed fact of the preservation of ATP and ADP levels is associated with the increased supply of the organism with energy substrates in the form of sucrose. At the same time, an increase in the AMP content in the mitochondrial fraction of rat liver can be considered as a compensatory reaction aimed at stabilizing the cellular energy status under the conditions of excessive sucrose intake. It is known that AMP is an activator of AMP-activated protein kinase (AMPK). AMPK plays a key role in maintaining the balance between anabolic and catabolic processes of cellular homeostasis in response to [the] metabolic stress [26]. AMPK is a metabolic switch sensitive to high AMP/ ATP ratios and functions to protect the energy state by inhibiting ATP-consuming processes while stimulating ATP-producing processes [27].

Noteworthy, the most significant changes in the energy supply of hepatocytes were observed under the conditions of a low-protein/ high-sucrose diet. It was found that under the conditions of different supply of protein and sucrose, a more than sixfold decrease in the succinate dehydrogenase activity was observed in the liver mitochondria (Fig. 1), while the cytochrome oxidase activity dropped to critically minimal values (Fig. 2). Besides, in the liver of rats kept on a protein-deficient diet with high sucrose content, a twofold increase in the hydrolytic activity of F0F1-ATPase compared to the control was found (Fig. 3). In conditions of a sharp decline of the succinate dehydrogenase activity and the cytochrome oxidase activity to critically minimal values, an activation of F0F1-ATPase can be aimed at maintaining the electrochemical potential due to the hydrolysis of ATP. When the transmem- brane electrochemical gradient of protons (proton motive force) is weak, the enzymes become an ATP-driven proton pump that rotates in the opposite direction, driven by the energy released by [the] ATP hydrolysis [28]. Moreover, under the conditions of a low-protein/high-sucrose diet, a decrease in the content of all adenyl nucleotides (Fig. 4-6) indicates that an unbalanced diet deepened the imbalance of the energy supply system. According to literature, a decrease in the adenyl nucleotides content by $15-20 \%$ leads to a depression of all energy-dependent processes in the cell by $75-80 \%$ [29], and primarily to the failure of synthetic processes in the liver. Additionally, whereas a decrease in the ATP content is probably caused by a slowdown in its resynthesis due to disruption of the structural and functional organization of the respiratory chain, the depletion of the AMP pool may be due to a decrease in its synthesis de novo under the conditions of protein deficiency. In the cell, the adenine nucleotides ATP, ADP, and AMP are tied directly or indirectly to all energetic pathways and allosterically control numerous regulatory enzymes [27]. Therefore, the revealed depletion of the pool of adenyl nucleotides in the liver mitochondria of rats kept on a low-protein/high-sugar diet will likely result in a disruption of numerous metabolic and energy-dependent processes in hepatocytes.

\section{Conclusions}

In hepatocytes, the maximum decrease in the activity of respiratory chain enzymes and an increase in the F0F1-ATPase activity followed by a decrease in the content of adenyl nucleotides to critically low values were found under the conditions of the low-protein/high-sucrose 
diet. It was concluded that the lack of protein in the diet is a determining factor for the system of energy supply and the functioning of the respiratory chain, whereas the imbalance in the diet in terms of the content of food protein and sucrose is critical for the formation of an imbalance in energy supply to hepatocytes. The obtained results open up the prospects for developing a strategy for correcting energy metabolism disorders in the conditions of nutritional imbalance.

\section{Funding}

The work was done within framework of the "Biochemical and laser-polarimetric parameters of complex forecasting of metabolic disturbances" program, State Register No $0119 \mathrm{U} 100717$.

\section{REFERENCES}

1. Castellanos JAK, Rodríguez PSM, Cardoso $S G$, Díaz DE, Tejero BME, del Bosque PL, Carbó ZR. Adipose tissue redistribution caused by an early consumption of a high sucrose diet in a rat model. Nutr Hosp. 2015; 31(6): 2546-53.

2. Jørgensen $W$, Rud KA, Mortensen OH, Frandsen L, Grunnet N, Quistorff B. Your mitochondria are what you eat: a high-fat or a high-sucrose diet eliminates metabolic flexibility in isolated mitochondria from rat skeletal muscle. Physiol Rep. 2017; 5(6): e13207.

3. Aw WC, Youngson NA, Ballard JWO. Can we alter dietary macronutrient compositions and alleviate mitochondrial disease? J Rare Dis Res Treat. 2016; 1(3):31-7.

4. Rodríguez-Correa E, González-Pére I, ClavelPérez PI, Contreras-Vargas Y, Carvajal K. Biochemical and nutri-tional overview of diet-induced metabolic syndrome models in rats: what is the best choice? Nutr Diabetes. 2020; 10:24.

5. van Zutphen T, Ciapaite J, Bloks VW, Ackereley C, Gerding A, Jurdzinski A, de Moraes RA, Zhang L,
Wolters JC, Bischoff R, Wanders RJ, Houten SM, Bronte-Tinkew D, Shatseva T, Lewis GF, Groen AK, Reijngoud DJ, Bakker BM, Jonker JW, Kim PK, Bandsma RH. Malnutrition-associated liver steatosis and ATP depletion is caused by peroxisomal and mitochondrial dysfunction. J Hepatol. 2016; 65(6): 1198-208.

6. Sangar V, Eddy JA, Simeonidis E, Price ND. Mechanistic modeling of aberrant energy metabolism in human disease. Front Physiol. 2012; 25(3):404.

7. Shimada S, Maeda S, Hikita M, Mieda-Higa K, Uene S, Nariai Y, Shinzawa-Itoh K. Solubilization conditions for bovine heart mitochondrial membranes allow selective purification of large quantities of respiratory complexes I, III, and V. Protein Expr Purif. 2018; 150:33-43.

8. Dobrelia NV, Boitsova LV, Danova IV. Legal basis for conducting ethical expertise in preclinical studies of medical products using laboratory animals. Sixth National Congress on Bioethics. 2016; 47.

9. European Convention for the Protection of Vertebrate Animals used for Experimental and Other Scientifi c Purposes. European Treaty Series No. 123 Strasbourg, 18.III.1986. Strasbourg: Council of Europe; 1986. $53 \mathrm{p}$.

10. Reeves P, Nielsen F, Fahey G. AIN-93 purified diets for laboratory rodents: final report of the American Institute of Nutrition ad hoc writing committee on the reformulation of the AIN-76A rodent. J Nutr. 1993; 123(11):1939-51.

11. Fernandes-Lima F, Monte L, Nascimento F, Gregório $B$. Short exposure to a high-sucrose diet and the first 'hit' of nonalcoholic fatty liver disease in mice. Cells. Tissues Organs. 2016; 201(6): 464-72.

12. Aoun M, Feillet-Coudray C, Fouret G, Chabi B, Crouzier D, Ferreri C, Chatgilialoglu C, WrutniakCabello C, Cristol JP, Carbonneau MA, Coudray C. Rat liver mitochondrial membrane characteristics and mitochondrial-functions are more profoundly altered by dietary lipid quantity than bydietary li-pid quality: effect of different nutritional lipid patterns. Br J Nutr. 2011; 107 (5):647-59.

13. Bradford MM. A rapid and sensitive method for the quantitation of microgram quantities of protein 
utilizing the principle of protein-dye binding. Anal Biochem. 1976; 72:248-54.

14. Ahmad F, Alamoudi W, Haque S, Salahuddin M, Alsamman $K$. Simple, reliable, and time-efficient colorimetric method for the assessment of mitochondrial function and toxicity. Bosn J Basic Med Sci. 2018; 18(4):367-74.

15. Straus $W$. Colorimetric microdetermination of cytochrome c oxidase. Biol Chem. 1954; 207:733-43.

16. Gabibov MM. Effect of hyperbaric oxygenation on proton ATPase activity in mitochondria of various rat tissues. Ukr Biokhim Zh. 1986; 58(5):81-3.

17. Zarubina IV, Krivoruchko BI. Separation and direct quantification of adenine nucleotides on silofole. Ukr Biokhim Zh. 1982; 54(4): 437-39.

18. Kopylchuk GP, Voloshchuk OM. NADH:ubiquinone reductase and succinate dehydrogenase activity in the liver of rats with acetaminopheninduced toxic hepatitis on the background of alimentary protein deficiency. Ukr Biochem J. 2015; 87(1): 121-26.

19. Pannala VR, Camara AKS, Dash RK. Modeling the detailed kinetics of mitochondrial cytochrome c oxidase: catalytic mechanism and nitric oxide inhibition. J Appl Physiol. 2016; 121:1196-207.

20. Zheng $J$, Ramirez VD. Inhibition of mitochondrial proton F0F1-ATPase/ATP synthase by polyphenolic phytochemicals. Br J Pharmacol. 2000; 130(5): 1115-23.

21. Huang LJ, Hsu C, Tsai TN, Wang SJ, Yang RC. Suppression of mitochondrial ATPase inhibitor protein (IF1) in the liver of late septic rats. Biochim Biophys Acta. 2007; 1767 (7):888-96.

22. Mikirova N, Riordan HD, Kirby RK, Klykov A, Jackson JA. Monitoring of ATP levels in red blood cells and t cells of healthy and ill subjects and the effects of age on mitochondrial potential. $J$ Orthomol Med. 2004; 20(1):50-8.

23. Ruiz-Ramírez A, Chávez-Salgado $M$, PeñedaFlores JA, Zapata E, Masso F, El-Hafidi M. Highsucrose diet increases ROS generation, FFA accumulation, UCP2 level, and proton leak in liver mitochondria. Am J Physiol Endocrinol Metab. 2011; 301(6): E1198-E1207.

24. Corte KWD, Perrar I, Penczynski KJ, Schwingshack L, Herder C, Buyken AE. Effect of dietary sugar intake on biomarkers of subclinical inflammation: a systematic review and meta-analysis of intervention studies. Nutrients. 2018; 10(5):606.

25. Schutt AK, Chellakkan SBW, Cecilia T, William E, Farook J, Yallampalli C. Preovulatory exposure to a protein-restricted diet disrupts amino acid kinetics and alters mitochondrial structure and function in the rat oocyte and is partially rescued by folic acid. Reprod Biol Endocrinol. 2019; 17(12):25-38.

26. Kim J, Yang G, Kim Y, Kim J, Ha J. AMPK activators: mechanisms of action and physiological activities. Exp Mol Med. 2016; 48:e224.

27. Berglund ED, Lee-Young RS, Lustig DG, Lynes SE, Donahue E., Camacho RC, Meredith ME, Magnuson MA, Charron MJ, Wasserman DH. Hepatic energy state is regulated by glucagon receptor signaling in mice. J Clin Invest. 2009; 119(8):2412-22.

28. Beyenbach $K W$, Wieczorek $H$. The V-type $\mathrm{H}+-$ ATPase: molecular structure and function, physiological roles and regulation. $J$ Exp Biol. 2006; 209(4):577-89.

29. Li CY, Liu JZ, Wu LP. Effects of hypobaric hypoxia on adenine nucleotide pools, adenine nucleotide transporter activity and protein expression in rat liver. World J Gastroenterol. 2006; 12(13):2120-24.

\section{Показники системи енергозабезпечення у печінці щурів за умов різної забезпеченості харчового раціону нутріснтами}

О. М. Волощук, Г. П. Копильчук

Мета. У роботі досліджені особливості енергозабезпечення гепатоцитів щурів за умов різної забезпеченості раціону протеїном та сахарозою. Методи. Експериментальні дієти, диференційне центрифугування, спектрофотометричні, хроматографія на пластинах Silufol. Результати. Встановлено, що за умов чотиритижневого утримування щурів на низькопротеїновому раціоні у гепатоцитах спостерігається зниження у 2.2 рази активності сукцинатдегідрогенази та втричі активності цитохромоксидази при супутньому підвищенні активності $\mathrm{F}_{0} \mathrm{~F}_{1}$-АТФази у 1,5 рази. За досліджуваних умов у мітохондріях гепатоцитів щурів спостерігається зниження вмісту АТР на 40 \% на тлі підвищення вмісту ADP та збереженні на рівні контр- 
олю вмісту АМР. Водночас за умов утримання щурів на високосахарозному раціоні у мітохондріях гепатоцитів не спостерігається достовірних змін активності сукцинатдегідрогенази, проте знижується вдвічі активність цитохромоксидази та зростає в 1.8 рази активність $\mathrm{F}_{0} \mathrm{~F}_{1}$-АТФази. Найвираженіші зміни енергетичного забезпечення гепатоцитів спостерігаються за умов споживання низькопротеїнового/високосахарозного раціону. Встановлено зниження активності сукцинатдегідрогенази у понад 6 разів та активності цитохромоксидази до критично мінімальних значень. Водночас підвищення гідролітичної активності $\mathrm{F}_{0} \mathrm{~F}_{1}$-АТФази вдвічі порівняно з контролем супроводжується виснаженням пулу аденілових нуклеотидів. Висновки. Зроблено висновок, що саме нестача протеїну у раціоні $є$ визначальним фактором для системи енергозабезпечення клітин та функціонування дихального ланцюга, при цьому порушення збалансованості раціону за вмістом харчового протеїну та сахарози $\epsilon$ критичним для формування дисбалансу енергозабезпечення гепатоцитів. Отримані результати відкривають перспективи для розробки стратегії корекції порушення енергетичного обміну за умов нутрієнтного дисбалансу.

К л ю ч о в і с с л о в а: сукцинатдегідрогеназа, цитохромоксидаза, $\mathrm{F}_{0} \mathrm{~F}_{1}$-АТФаза, печінка, нутрієнти

\section{Показатели системы энергообеспечения в печени крыс в условиях различной} обеспечености пищевого рациона нутриентами

\section{О. Н. Волощук, Г. П. Копыльчук}

Цель. В работе исследованы особенности энергообеспечения гепатоцитов крыс в условиях различной обеспеченности рациона белком и сахарозой. Методы. Экспериментальные диеты, дифференциальное центрифугирование, спектрофотометрические, хроматография на пластинках Silufol. Результаты.
Установлено, что в условиях 4-недельного содержания крыс на низкопротеиновом рационе в гепатоцитах наблюдается снижение в 2,2 раза активности сукцинатдегидрогеназы и втрое активности цитохромоксидазы при одновременном повышении активности $\mathrm{F}_{0} \mathrm{~F}_{1}$-АТРазы в 1,5 раза. В исследуемых условиях в митохондриях гепатоцитов крыс наблюдается снижение содержания АТФ на $40 \%$ на фоне увеличения содержания АДФ и сохранения на уровне контроля содержания АМФ. В то же время при содержании крыс на высокосахарозном рационе в митохондриях гепатоцитов не наблюдается достоверных изменений активности сукцинатдегидрогеназы, но вдвое снижается активность цитохромоксидазы и повышается в 1,8 раза активность $\mathrm{F}_{0} \mathrm{~F}_{1}$-АТФазы. Наиболее выраженные изменения энергообеспечения гепатоцитов наблюдаются в условиях употребления низкобелкового/высокосахарозного рациона. Установлено снижение активности сукцинатдегидрогеназы в более чем 6 раз и активности цитохромоксидазы до минимальных значений. В то же время повышение гидролитической активности $\mathrm{F}_{0} \mathrm{~F}_{1}$-АТФазы вдвое в сравнении с контролем сопровождается истощением пула адениловых нуклеотидов. Выводы. Сделан вывод, что именно дефицит белка в рационе является определяющим фактором для системы энегообеспечения клеток и функционирования дыхательной цепи, при этом нарушение сбалансированности рациона по содержанию белка и сахарозы является критическим для формирования дисбаланса энергообеспечения гепатоцитов. Полученные результаты открывают перспективы для разрабоки стратегии коррекции нарушения энергетического обмена в услових нутриентного дисбаланса.

К л юч е в ы е с л о в а: сукцинатдегидрогеназа, цитохромоксидаза, $\mathrm{F}_{0} \mathrm{~F}_{1}$-АТФаза, печень, нутриенты

Received 25.05.2021 